\section{Ritual Mandi Pengantin: Kecemasan, Harapan dan Tafsir Simbolis tentang Masa Depan}

Indonesian Journal of Religion and Society, 2021, Vol. 03 (01), 10-20

(C) The Journal, 2020

DOI: $10.36256 /$ ijrs.v3i1.148

www.journal.lasigo.org/index.php/IJRS

aysterournal

Article History

Received: May 20th, 2021

Revised: June 26th 2021

Accepted: June 28th 2021

\title{
Nurmasitah
}

Universitas Islam Negeri (UIN) Imam Bonjol Padang, Indonesia

Nurmasitah636@gmail.com

\section{Muliono}

Universitas Islam Negeri (UIN) Imam Bonjol Padang, Indonesia Muliono191@gmail.com

\begin{abstract}
Bridal bath ritual reflects a symbolic system and has a relation to the being, the sacred and the profane. Phenomenologically, this study is intended to discuss the ritual of bridal bathing. The approach used to reveal the ritual's meaning is the interpretation of symbolic. This study used a qualitative. The social setting of this research was carried out in community of Banjar, in the Tambilahan. Data were collected through interviews, observation and documentation. This study shows that the bridal bath ritual has three fundamental aspects in which the ritual is practiced by Banjar community. First, as a culture heritization of the ancestors. Second, as a diealectic of feelings: fear and hope in the life of the bride family. Third, as a symbolic reflection of the sacred values. The bridal bath ritual on the sequel becomes a path for the brides and their families to spared the disturbance of the being or evil orchestra, repudiating the fear, the anxiety, and as a path of household resilience in the future.
\end{abstract}

Keywords: Bridal Bath Ritual; Marriage; Symbolic Systems.

\begin{abstract}
ABSTRAK
Ritual mandi pengantin merefleksikan suatu nilai simbolik dan melibatkan relasi kepada yang ghaib, sakral dan profan. Ada harapan, kecemasan, dan tafsir simbolik tentang masa depan pengantin. Studi ini dimaksudkan untuk mendiskusikan secara fenomenologis ritual mandi pengantin. Pendekatan yang digunakan untuk mendedah makna ritual adalah konsep ritual dan konsep interpretasi simbolik Geertz. Penelitian ini menggunakan metode kualitatif deskriptif analitis. Setting penelitian dilakukan pada masyarakat Banjar di Tambilahan, Indragiri Hilir. Data dikumpulkan melalui wawancara, observasi dan dokumentasi. Studi ini menunjukkan bahwa tradisi mandi memiliki tiga aspek fundamental dalam mana ia menjadi keharusan dipraktikan masyarakat Banjar. Pertama, sebagai heritasi kultur para leluhur. Kedua, sebagai diealektika rasa (takut dan harap) terhadap kehidupan rumah tangga pengantin. Ketiga sebagai reflektif simbolis nilai-nilai sakralitas. Tradisi mandi pengantin pada kelanjutannya menjadi jalan agar pengantin dan keluarga terhindar dari gangguan mahkluk ghaib, menolak rasa ketakutan dan kecemasan serta sebagai jalan untuk ketahanan rumah tangga masa depan.
\end{abstract}

Kata Kunci: Ritual Mandi, Pernikahan, Sistem Simbolik. 


\section{Pendahuluan}

Pernikahan memiliki makna sakral hampir di setiap masyarakat belahan dunia. Pernikahan tidak saja untuk melanggengkan relasi seksual secara legitim yang dibangun berdasarkan sosio-kultural, tetapi juga memiliki tautan makna kepada yang transenden. Segi transendensi pernikahan diejawantahkan melalui berbagai prosesi melibatkan kultur atau tradisi dimana masyarakat itu tumbuh. Konteks Indonesia sendiri menempatkan perkawinan kepada tiga ranah dalam mana keabsahanya dapat diterima. Ranah tersebut adalah ranah agama, budaya dan negara.

Relasi agama dan budaya secara dialogis sangat kentara di momentum pernikahan. Dan, ini didapati di setiap tradisi (Britannica, 2021; Procario-Foley, 2004; Southey, 2020). Kesakralan pernikahan ditunjukkan dalam berbagai praktik ritual. Praktik ritual secara konstruktif terus disosialisasi kepada anggota masyarakat; diinternalisasi, eksternalisasi, dan objektifikasi sebagai sebuah kenyaatan sosial (Dharma, 2019; Sulaiman, 2016; baca Berger \& Luckman, 2012). Paper ini mendedah secara fenomenologis mengenai praktik ritual pernikahan. Ritual pernikahan yang menjadi fokus kajian adalah ritual mandi pengantin. Studi ini menarik karena praktik mandi pengantin secara fenomenologis dimaknai sebagai suatu yang bermakna, penting dan dipercaya memiliki implikasi terhadap keberlanjutan kelanggengan keluarga di masa depan, memiliki nilai-nilai transendental dan magis yang berimplikasi kepada diri dan keluarga pengantin, serta bagaimana mandi sebagai suatu yang privat diinstitusikan menjadi publik. Ritual mandi pada praktisnya disaksikan masyarakat umum sebagai sebuah spectacle.

Beberapa studi membahas tentang tradisi dalam pernikahan baru seputar; pertama studi yang fokus pada dampak positif dan negatif dari pelaksanaan tradisi di daerah tertentu seperti pertama, studi Ariska (2017); Neliyanti (2020); Purnadi (2008); Putra, (2014); Shalihin (2016); Yosofi (2017). Kedua, studi yang fokus pada pandangan masyarakat terhadap pelaksanaan tradisi seperti studi Any (2016); Hasbullah \& Syahran Jailani (2020); Maskurin (2017); Mustofa (1967). Studi ini melengkapi studi-studi yang telah ada dan secara khusus menemukan makna mandi pengantin yang dikonstruksi masyarakat Banjar. Secara spesifik studi ini bertolak dari pertanyaan berikut. Pertama, mengapa mandi pengantin menjadi sesuatu yang penting bagi masyarakat Banjar? dan kedua, apa yang melarbelakangi keharusan mandi pengantin dalam masyarakat Banjar? Melalui pertanyaan ini, studi ini akan mendedah prosesi dan berbagai ornamen ritual mandi pengantin dan bagaimana mandi pengantin menjadi sebentuk harapan dan ketakutan tentang masa kini depan masa depan dalam pemaknaan masyarakat Banjar sehingga ritual mandi pengantin penting dan sebagai keharusan dilaksanakan.

\section{Kerangka Teori}

Studi ini menggunakan pendekatan konsep ritual dan konsep interpretasi simbolik. Dua pendekatan ini akan digunakan untuk memahami praktik ritual mandi pengantin yang menjadi fokus kajian dalam studi ini. Memahami ritual pada dasarnya mencoba untuk menginterpretasi berbagai makna simbolik yang tampak. Interpretasi makna simbolik melibatkan secara subjektif aktor-aktor yang terlibat dalam bagaimama mereka memahami dan memaknai tindakan itu dilakukan.

Ritual (rites) memiliki fungsi dalam kehidupan. Ritual berkaitan dengan hal-hal yang transenden (I Gede, 2019). Praktiknya dilaksanakan untuk memohon dan atau mendekatkan diri kepada sesuatu yang dianggap memiliki kekuatan luar biasa di luar daya kemampuan manusia. Pendekatan itu apakah untuk memperoleh berkah, rezeki, menolak mara-bahaya, sebagai perlindungan, menghindari atau pengobatan penyakit (rites of healing), serta memaknai siklus perubahan dalam fase kehidupan manusia (Koentjaraningrat, 1990). Menurut Longer ritual merefleksikan tatanan mengenai simbolsimbol yang diobjektivikasikan dan dipraksiskan ke berbagai perilaku dan peranan tertentu (Hendro, 2020). Ritual memiliki diferensiasi dalam setiap masyarakat seturut dengan kultur dimana ritual itu dipraktikkan. Ritual dihubungkan dengan berbagai momen antara kehidupan dan kematian; kelahiran, pernikahan, kehamilan, kematian, dan ekspresi terhadap kesakralan suatu yang dikultuskan sebagai yang khusus (Sumarlin, 2015).

Pada tataran ini, konsep fenomenologi berperan penting yang dapat memberi sumbangsih untuk mengungkap realitas sosial. Ada realitas yang tidak dapat diejawantahkan secara empirik dan hanya dapat dimaknai secara simbolis. Realitas ini biasanya dikategorikan sebagai realitas tertinggi (paramount reality). Suatu realitas atas penghayatan dan praktik kehidupan sehari- hari. Konsep fenomenologi dinisbahkan Schutz 
(Nindito, 2013) yang merupakan "pengilhaman" dari konsepsi Weber (Ritzer \& Stepnisky, 2019) mengenai verstehen. Dan, berkembang bagi pemikir selanjutnya seperti Berger dan Luckmann (Sulaiman, 2016). Juga memiliki relasi dengan perspektif metodologis Geertz tentang interpretasi budaya (Fitria, 2012). Geertz (dalam Fitria, 2012) meletakkan titik fokus pada pendekatan yang bisa dilakukan terhadap studi religi selain dari pendekatan yang telah berkembang seperti Freud (Turner, 2010, 2012) dengan teori identitas seksual yang sangat psikologis, Durkheim (dalam Turner, 2012) dengan teori kesakralan dan fakta sosial. Geertz mempromosikan pendekatan sistem kebudayaan untuk analisis praktik religi dan berbagai ritual yang menyertainya. Dan, untuk pentingan studi ini, studi akan menggunakan perspektif Geertz dalam menganalisa, memahami, serta menginterpretasi makna simbolik praktik ritual mandi pengantin.

\section{Metode Penelitian}

Studi ini menggunakan metode kualitatif dengan pendekatan deskriptif analitis untuk menganalisis dan menginterpretasi makna ritual mandi pengantin. Lokasi penelitian ini mengambil setting pada masyarakat Banjar di Tambilahan. Pemilihan tempat didasarkan pada populasi yang cukup banyak, tingkat representatif, telah bertempat tinggal dalam waktu cukup lama, dan secara tradisi cukup begitu kuat dipraktikkan oleh masyarakat Banjar di Tambilahan. Pengumpulan data dilakukan secara partisipatif dimana peneliti terlibat langsung dengan mendekati informan, baik dengan melakukan wawancara, observasi maupun dokumentasi. Proses pengambilan data wawancara dilakukan secara tidak terstruktur, dalam artian mengalir seperti percakapan biasa dengan informan tetapi tetap fokus pada masalah yang dikaji.

Studi ini melengkapi analisis data dengan pendekatan yang ditawarkan oleh Creswell (2019). (1) Manajemen data yaitu data-data yang telah ada disusun dengan cara dijadikan satu buah file khusus mengenai tema yang diteliti. (2) Pembacaan/memoing yaitu data yang berbentuk wawancara tersebut dibaca terlebih dahulu, kemudian dimemoing. Sementara untuk data wawancara diberikan catatan-catatan. (3) Deskriptif atau klasifikasi atau penafsiran, yaitu data-data yang telah ada digambarkan, jika data berbentuk wawancara (diceritakan) kemudian dicatat poin-poin yang dianggap penting. (4) Penyajian/visualisasi, yaitu data yang telah diperoleh dapat disajikan. Jika data tersebut berupa angket maka cara penyajiannya bisa dengan menggunakan grafik, diagram atau tabel. Jika data tersebut berupa wawancara maka penyajiannya bisa berupa narasi.

\section{Hasil dan Diskusi}

\subsection{Ritual Mandi Pengantin: Prosesi dan Ornamen yang Menyertai}

Menikah adalah salah satu momen sakral dalam fase kehidupan. Ada banyak proses yang harus dilalui. Mulai dari persiapan sampai berbagai prosesi ritual yang mesti dilakukan demi terselesaikannya keseluruhan rangkaian acara resepsi (Procario-Foley, 2004). Satu tradisi dilakukan masyarakat Banjar berkenaan dengan pernikahan adalah ritual mandi pengantin. Dan, ritual ini menjadi sebentuk tradisi. Tradisi mandi pengantin merupakan tradisi yang penting. Terdapat keyakinan ketika ritual ini tidak dilakukan dapat menyebabkan hal yang tidak diinginkan. Pada waktu bersamaan ritual mandi menjadi jalan untuk memperoleh sebentuk keberkahan.

Ritual mandi secara general diakui oleh masyarakat sebagai bagian dari Agama. Tepatnya adalah sebentuk proses singkritisme meskipun tidak seperti kebanyakan ritual di Jawa. Agama itu sendiri memiliki proposisi sistem kepercayaan yang memungkinkan individu untuk saling berhubungan satu sama lain, serta untuk menciptakan, memelihara dan memperkuat hubungan interpersonal dalam komunitas tertentu. Ritual dapat ditemukan setiap hari dan di mana pun karena masyarakat pada dasarnya adalah ritualistik. Ritual memiliki tiga fungsi utama yaitu; pertama, menghubungkan manusia dengan sang pencipta. Fungsi ini membutuhkan penggunaan simbol-simbol tertentu atau seperangkat simbol yang memungkinkan hubungan dibuat atau dipertahankan dengan yang ilahi. Kedua, sebagai media untuk mematuhi norma-norma sosial di tengah masyarakat. Jenis ritual ini membutuhkan kunjungan sosial, pertemuan dan pertemuan yang menegaskan nilai-nilai umum kelompok. Ketiga, menolak suatu ketakutan dan kecemasan. Fungsi ini adalah respons terhadap kesusahan, ketidakpastian, dan ketidakamanan yang ditimbulkan oleh kehidupan politik dan sosial sehari-hari (Humaeni, 2015). 
Prosesi mandi pengantin masyarakat Banjar diawali dengan membentuk pagar mayang yang dijadikan sebagai tempat mandi pengantin. Beberapa instrumen diperlukan membuat pagar mayang adalah empat buah batang tebu, empat buah kelapa yang bertunas, benang kuning, dan berbagai macam kue yang akan digantung pada benang kuning. Kue tersebut berupa kue cincin, kue cucur, kembang goyang, kerupuk dan pisang. Benang kuning dibuat dengan cara memberi warna kuning pada benang yang berwarna putih dengan bahan kunyit. Kemudian pagar mayang dibentuk persegi empat dengan tebu, kelapa dan benang kuning. Pagar mayang memiliki strukturnya satu atau tiga tingkat sebagai penghubung antar sisi. Selain itu, bahan berikutnya adalah empat jenis air yang akan digunakan untuk mandi mereka yang menjadi pengantin. Air tersebut ialah air biasa, air yasin, air kelapa dan air doa. Air yasin merupakan air yang sengaja disediakan dengan terlebih dahulu dibacakan surat yasin (salah satu surat dalam kitab alquran). Demikian air doa, air yang dibacakan oleh separangkat doa-doa kebaikan, doa keselamatan, dan sejenisnya. Dari segi peralatan, peralatan untuk mandi yaitu mayang pinang yang masih terbungkus, mayang pinang yang sudah terbuka bungkusnya, pakaian untuk pengantin ketika selesai mandi, kain untuk mandi, bedak kuning, tepung tawar (tetungkal), dan sabun yang diletakkan di dalam talam.

Ketika bahan telah tersedia, pengantin perempuan yang telah berpakaian rapi dan berhias turun dari rumah untuk menuju pagar mayang dimana proses mandi pengantin dilaksanakan. Ketika pengantin perempuan turun akan disambut oleh pengantin laki-laki dan diserta dengan dibacakannya kalimat-kalimat shalawat. Kalimat shalawat merupakan kalimat yang ada dalam tradisi Islam sebagai sebentuk pujian, penghormatan, dan sekaligus doa untuk Nabi (the prophet). Secara maknawai, kalimat shalawat juga difahami bukan saja sebagai pujian kepada Nabi tetapi ijrs.v3i1.148 juga sebagai doa untuk mereka yang mengucapkannya. Demikian, shalawat banyak ditemukan ragam dan langgamnya tersebar di berbagai daerah seturut dengan tradisi masing-masing.

Sebelum mandi, turun pengantin perempuan kemudian pengantin laki-laki menjemput pengantin perempuan kemudian bersama-sama mengelilingi pagar mayang, jika ada keturunan beusung dan besilat, maka beusung dan besilat terlebih dahulu sebelum mandi, jika tidak ada maka langsung saja mandi. Pada kelilingan yang ketiga pengantin saling berjalan berputar arah menuju tempat mandi (Timrah, wawancara, 2019).

Mandi pengantin dilakukan umumnya di halaman rumah dengan menggunakan pagar mayang. Pelaksanaan mandi pengantin ini adalah pada sore atau malam hari. Mandi pengantin dilakukan oleh tiga orang perempuan yang memiliki kemafhuman adat atau bidan kampung. Upacara mandi pengantin secara lebih longgar dilakukan, dimana didapati keturunan pada saat mandi pengantin harus disandingkan, namun ada juga yang melaksanakan mandi pengantin dengan tidak disandingkan atau cukup dilakukan di dalam rumah. Mandi pengantin yang dilakukan dengan disandingkan maka pengantin harus terlebih dahulu mengelilingi pagar mayang dan memakai pakaian untuk mandi. Kemudian pengantin duduk di kursi yang telah disediakan di dalam pagar mayang. Orang pertama mulai memandikan pengantin dengan air biasa yang berisi mayang di dalamnya, dilakukan secara bergantian. Selama mandi diiringi dengan pukulan gong dan gendang yang dilakukan mereka sebagai pengawal.

Saat akan memandikan, bacakan shalawat Nabi. Ada tiga macam air yang digunakan untuk mandi, setelah selesai memandikan dengan air biasa secara bergantian 3 kali sambil membaca shalawat dengan mayang kambang. Setelah selesai mandi dengan air biasa baru dengan mayang bungkus cukup satu orang yang menyiram dan satu lagi memegang mayangnya. Air kelapa muda yang pertama baru air yasin dan terakhir air doa. Air kelapa, yasin dan doa tersebut harus diminum karena jika banyak diminum makan akan banyak pula rezekinya. Mayang pinang yang masih terbungkus tadi kemudian dipukul/ditepuk, jika satu kali tepukan mayangnya pecah artinya anaknya kelak perempuan jika dua kali tepukan baru pecah artinya anaknya kelak laki-laki. setelah mayang dipukul kemudian diletakkan sedikit saja di telinga pengantin, setelah itu kalau biasa yang akan mengambil mayang di telinga pengantin tadi adalah orang lain dengan menggunakan giginya. Tujuannya mayang tersebut bagus untuk umpan pancing begitupun dengan benang kuning yang dijadikan pagar mayang tersebut. Untuk benang kuning sendiri boleh dibuat satu tingkat boleh juga tiga tingkat karena banyak orang yang ingin mengambil benang tersebut (Jainab, wawancara, 2019).

Pengantin mandi dengan disandingkan, pagar mayang harus ada. Pagar mayang tersebut terdiri dari kelapa 4 batang, tebu 4 batang, benang kuning dan berbagai macam kue (cucur, cincin, pisang, kerupuk). Pada saat mandi harus dengan mayang pinang baik 
yang masih terbungkus ataupun yang sudah terbuka. Selesai mandi yang harus ada minyak, bedak, sisir, lilin dan cermin, serta kue seperti dodol putih, dodol merah, air kinca, pulut dan telur. Pada saat mandi harus dengan mayang pinang baik yang masih terbungkus ataupun yang sudah terbuka. Selesai mandi yang harus ada minyak, bedak, sisir, lilin dan cermin, serta kue seperti dodol putih, dodol merah, air kinca, pulut dan telur. Tempat untuk mandi biasanya di depan rumah jika disandingkan, dan jika tidak disandingkan biasanya mandi pengantin hanya dilakukan di kamar mandi. Untuk membuat pagar mayang yang diperlukan yaitu 4 batang tebu, 4 kelapa, benang kuning, berbagai macam kue (ada yang 40 kue dan ada yang 7 kue). Benang kuning bisa dibuat satu tingkat dan bisa juga tiga tingkat.

Pasca mandi, pengantin akan diwadaki (bedak yang di campur dengan kunyit) pada bagian tangan sebelah kanan kiri dan muka. Rambut pengantin disisiri, ditetungkali (air yang dicampur dengan potongan pandan), kemudian pengantin dimandikan lagi dengan air biasa yang pertama secara bergantian (3 orang yang memandikan). Setelah selesai menggunakan jenis air biasa, dilanjutkan dengan air kelapa, doa dan yasin dengan memakai mayang yang masih terbungkus secara bergantian. Pada saat dimandikan dengan air kelapa, yasin dan air doa, pengantin harus sambil meminum air tersebut. Selesai dimandikan, mayang dipukul sampai pecah. Bagian dalam mayang diambil sedikit dan diletakkan pada bagian telinga pengantin. Setelah itu pengantin berganti pakaian untuk kemudian masuk kembali ke dalam rumah.

\begin{abstract}
Setelah mandi, pengantin duduk di atas kasur, pertama pengantin disurui dilakukan sebanyak tiga kali secara bergantian (orang yang memandikan tadi), kemudian bepupur baru diminyaki bisa dengan minyak kemiri sedikit-sedikit, kemudian dikelilingi dengan lilin dan cermin, setelah itu siapa yang duluan meniup lilin. Yang bagian hitam pada lilin diletakkan di hujung hati pengantin perempuan dan laki-laki, jika laki-laki tidak, yang penting di ujung hati pengantin perempuannya. Sebagai penerang hati. Jika ada rokok kedua pengantin disuruh merokok bergantian, setelah itu minum air kinca sedikit-sedikit, makan telur dan pulut, makan bubur putih dan merah. Pada saat mandi pengantin juga pakai tetungkal, kemudian air tetungkal itu disimpan atau diletakkan di kamar pegantin. Dan jika adatnya beusung dan besilat harus pakai beusung dan besilat dalam mandi pengantin (Jainab, Wawancara, 2019).
\end{abstract}

Ketika pengantin telah di dalam rumah dan duduk di atas kasur, mereka yang memandikan pengantin kemudian menyisir rambut pengantin secara bergantian dan diberi minyak rambut, selanjutnya wajah pengantin di kasih bedak, bisa juga mata pengantin dipakaikan celak mata, kelilingkan lilin bersamaan dengan cermin. Kemudian lilin dimatikan (ditiup), pada bagian ujung lilin letakkan pada bagian ujung hati pengantin lakilaki dan perempuan, boleh juga hanya pada pengantin perempuan saja. Setelah itu bacakan doa selamat dan kemudian pengantin akan makan dodol putih, dodol merah, pulut dan telur, terakhir minum air kinca (santan yang dicampur dengan gula merah).

Secara prinsip tidak semua orang dapat memandikan pengantin, karena mandi pengantin biasanya dipimpin oleh orang yang paham tentang adat mandi dan harus berjumlah tiga orang. Kemafhuman ini penting agar prosesi mandi tidak dilaksanakan secara asal-asalan. Di Tambilahan, biasanya yang paham dengan adat tersebut mayoritas adalah bidan kampung meskipun tidak menutup kemungkinan selain dari bidan. Mereka yang terlibat dalam memandikan pengantin diutamakan memiliki relasi hubungan kekeluargaan dengan pengantin dan berjenis kelamin perempuan, tidak boleh laki-laki. Ini dikarenakan pada saat mandi, pengantin membuka auratnya (pada bagian kepala perempuan atau tidak memakai jilbab). Namun seiring perkembangan zaman terdapat modifikasi-modifikasi. Sebagian menutup auratnya bahkan mengenakan jilbab.

Selain syarat di atas, ada beberapa hal lain yang tidak boleh untuk ditinggalkan. Apabila tidak dilaksakan diyakini akan berdampak pada pengantin atau keluarganya dikemudian hari. Masyarakat Banjar meyakini apabila tradisi ini terus dijaga keberkanjutannya, maka kehidupan rumah tangga pengantin akan jauh dari gangguan.

Mengambil air biasa untuk mandi harus dengan gendang yang dipukul dengan pukulan khusus dan tidak sembarang pukul. Karena orang dahulu ada yang salah satu tinggal prosesnya dalam memandikan setelah melahirkan anaknya lemah dan umurnya pun tidak panjang (meninggal), (Timrah 2019). Lalu, dodol putih, dodol merah, kue cucur dan kue cincin harus selalu ada karena dodol dan kue tersebut juga harus ada ketika mandi 7 bulan kehamilan (Sakdiah, Wawancara, 2019).

Hasil wawancara dengan beberapa narasumber menegaskan ada yang berbeda dari beberapa adat Banjar (ada Banjar Alai, Banjar Kandangan dan Banjar Kalua). Setiap adat 
banjar dalam mandi pengantin tersebut ada yang tidak boleh untuk ditinggalkan karena akan menimbulkan efek yang tidak baik apabila hal tersebut diabaikan. Hal yang tidak boleh ditinggakkan tersebut diataranya; dodol putih, dodol merah, pulut dan telur, air kinca, dan beras kuning. Berdasarkan hasil observasi yang telah dilakukan, hal tersebut memang selalu ada, karena bahan-bahan yang diperlukan untuk membuat kue tersebut cukup mudah untuk di dapatkan, dan proses membuatnya pun tidak memakan waktu yang lama. Karena apabila hal tersebut diabaikan maka akibatnya akan ada yang kesurupan, pingsan dan lain sebagainya yang akan mengganggu jalannya proses perkawinan.

Jika pelaksanaan mandi pengantin tidak dengan disandingkan, maka dapat dilaksanakan di dalam rumah. Prosesinya, mandi harus menghadap matahari. Disediakan pulut dan mayang pinang. Pulut diletakkan sedikit dalam piring dan ditambahkan satu butir telur yang telah direbus. Telur itu harus dimakan oleh pengantin.

Masyarakat Banjar yang ada di Tembilahan masih sangat mempercayai apabila ada alat tersebut yang ditinggalkan, maka akan ada yang kesurupan bagi siapa saja yang "lemah bulu". Alat yang tidak boleh ditinggalkan tersebut tergantung kepada keturunan masingmasing suku Banjar. Ada yang harus mandi disandingkan dengan menggunakan pagar mayang dan ada juga yang tidak menggunakan pagar mayang, karena sebagian dari mayarakat Banjar sudah ada yang menghilangkan tradisi mandi pengantin dengan disandingkan. Ada yang mandinya tidak perlu disandingkan, cukup mandi seperti biasa tetapi harus tetap menggunakan air Yasin dan doa.

\title{
4.2. Fear and Hope: Tradisi Mandi Pengantin dan Pemaknaan Tentang Masa Depan
}

Tradisi mandi pengantin mempunyai makna penting bagi masyarakat Banjar. Mandi pengantin dilakukan sekali seumur hidup pada pernikahan pertama. Mandi dipandang sebagai simbolisme yang mengandung makna tidak saja sebagai "heritasi kultural" para leluhur, tetapi juga pada penyucian diri, rasa takut akan kehidupan rumah tangga pengantin di masa depan, dan masalah nilai sakralitas. Masyarakat Banjar mempercayai ketika tradisi mandi dibudaya-lestarikan akan memberi dan mendatangkan sebentuk keberkahan dalam kehidupan rumah tangga pengantin. Sebaliknya, dipercaya mendatangkan sesuatu yang buruk atau bahkan malapetaka.

\begin{abstract}
Perkawinan hendaknya dilakukan sekali seumur hidup, pengantin ibarat raja, jadi dirajakan hanya ketika melakukan perkawinan yang pertama, jika perkawinan yang kedua, maka tidak lagi pakai mandi pengantin. orang yang mandinya disandingkan itu, terkadang hanya untuk tujuan meramaikan pengantinan saja, bukan keturunan. Tapi kalau keturunan Banjar alay memang harus bersanding ketika mandi pengantin. kadang pengantin laki-laki belum mandi, jadi sekalian mandi besanding dengan pengantin perempuan. kebanyakan seperti itu, kalau Banjar Alay mandinya harus bersanding, besilat dan beusung yang dilakukan ketika hari pengantinan. Kalau tidak mandi pengantin, kadang-kadang ada yang mengganggu seperti tidak sadarkan diri (pingsan) kalau tidak pernah dimandikan. Memang ada bacaan-bacaan khusus saat mandi pengantin. Tujuan mandi pengantin agar pengantin terlihat cantik (Jamilah 2020).
\end{abstract}

Berdasarkan pengalaman secara historis di masyarakat Banjar, ketika mandi pengantin tidak dilaksanakan terjadi hal mistis yang biasanya bersifat negatif. Misalnya pengantin tidak sadarkan diri secara tiba-tiba (pingsan), bertingkah seperti orang gila baik itu dari pengantinnya ataupun pihak keluarga. Ada sebentuk magis tersendiri. Lebih dari itu, eksistensi rumah tangga juga didapati tidak "bernafas langgeng", bahkan dapat berdampak kepada kematian atau anak yang dilahirkan tidak dapat memiliki umur yang panjang. Atas kondisi ini, masyarakat meyakini adanya gangguan di luar nalar manusia ketika tradisi ditinggalkan dalam jalannya resepsi perkawinan. Tidak sampai di situ, dampaknya juga membawa keburukan bagi kehidupan rumah tangga pengantin di masa depan.

Tradisi mandi menghadirkan makna harapan dan sekaligus rasa takut (fear and hope). Adanya ketakutan terhadap kehidupan rumah tangga pengantin di masa depan jika tradisi ini ditinggalkan. Kehidupan rumah tangga pengantin tidak akan bertahan lama (tidak langgeng). Kehidupan rumah tangga tidak akan harmonis selayaknya rumah tangga yang diinginkan setiap orang (Naldini, 2017). Sementara secara substantif tujuan pernikahan adalah kehidupan rumah tangga yang sakinah, mawaddah dan warahmah (Qurtubi, tt). Untuk menghindari hal tersebut orang Banjar terus melestarikan tradisi mandi pengantin sampai saat ini. Ketakutan ini mendasari dilakukannya ritual mandi sekaligus sebagai harapan kebaikan di masa depan. 
Bagi orang Banjar ada beberapa alat yang harus ada ketika tradisi mandi pengantin. Setiap alat mengandung arti yang membawa kepada kebaikan. Salah satu alat yang digunakan dalam pelaksanaan tradisi ini adalah pagar mayang. Pagar mayang: nisan/tebu, kelapa yang tumbuh/bertunas (masing-masing 4 buah), kue yang digantung ada kue cucur, kembang goyang, pinang yang kecil-kecil dan kelapa yang kecil-kecil, pisang masak digantung tiga tingkatan. Kelapa yang dijadikan pagar mayang tersebut ditanam yang melambangkan kehidupan rumah tangga kelak. Tebu melambangkan manisnya kehidupan berumah tangga.

Makna dari tebu adalah untuk membuat "kandang" agar pengantin tidak diganggu. Sehingga daripada itu, diberi pagar dengan batang tebu. Hakikat hati ingin kehidupan rumah tangganya kelak semanis tebu. Kelapa memberi arti bahwa kelapa adalah tumbuhan yang mudah hidup di mana saja dan kelapa dapat menjamin hidup secara turun-temurun karena kelapa tumbuhan yang bisa bertahan hidup cukup lama dan menghasilkan. Arti dari mayang pinang berdasarkan folklore ialah putri kayangan yang suka mencium aroma wewangian dari manyang. Manfaat dari bedak kuning untuk membersihkan supaya pengantin cantik dan berseri. Hakikat dari sisir agar rambut terlihat rapi dan enak dipandang. Lilin hakikatnya agar memberi cahaya terang terhadap kehidupan. Hakikat dari cermin adalah mencerminkan mana yang baik dan buruk. Dodol putih, dodol merah dan pulut memudahkan datuk dan nenek yang ingin memakannya. Ini merupakan makanan kesukaan dari datuk dan nenek dan meminta berkahnya. Kue dan dodol tersebut mesti dibacakan doa mehalarat, agar jodoh bisa lengket seperti pulut antara suami dan istri. Masing-masing alat tersebut memberi makna yang baik untuk kehidupan rumah tangga yang akan dijalani pengantin, alat tersebut menggambarkan agar kehidupan yang akan dijalani penuh keharmonisan dan kerukunan hingga akhir hayat.

Lebih lanjut, bagi masyarakat Banjar, kelapa memberi arti kehidupan rumah tangga pengantin hendaknya banyak membawa manfaat baik untuk kehidupan rumah tangga, keluarga dan lingkungan sekitarnya karena bagian dari kelapa mulai dari daun, buah dan batang dapat digunakan dan memberi manfaat. Sedangkan benang kuning dipercaya memudahkan untuk mendapatkan ikan ketika digunakan untuk memancing, sehingga banyak orang yang ingin mendapatkan benang kuning ini. Mayang pinang memberi arti bahwa apabila pada saat mandi mayang pinang yang masih terbungkus akan ditepuk, apabila satu kali tepukan mayang berhasil terbuka maka anak pertama dari pengantin adalah laki-laki dan apabila dua kali tepukan mayang pinang baru terbuka maka anak pertamanya adalah perempuan. Mayang yang telah terbuka memberi makna bahwa setiap orang menyukai wewangian jadi dari mayang pinang terdapat aroma yang harum. berbagai macam kue yang digantung pada saat pengantin mandi mengandung kebaikan apabila dimakan dan kue tersebut menjadi rebutan orang yang menyaksikan mandi pengantin. setiap orang yang melihat mandi pengantin menginginkan apa saja yang ada pada saat pengantin mandi.

Masyarakat Banjar difahami, melalui ritual mandi pengantin, mempelihatkan mekanisme lokal sendiri untuk menuntun dalam bagaimana kehidupan ke masa depan. Tradisi mandi pengantin di samping sebagai bentuk penolak bala, juga dijadikan sebagai prediksi eskatologis tentang kemungkinan kelahiran anak. Apakah berjenis kelamin perempuan atau berjenis kelamin laki-laki. Melalui ritual berbagai perubahan dapat diramalkan untuk kemudian diantisipasi. Perubahan yang dimaksud pada umumnya berkaitan dengan aspek fisiologis; kelahiran, pernikahan dan kematian. Melalui peristiwaperistiwa ini, individu masuk ke dalam relasi baru yang secara sosiologis memiliki makna yang baru pula. Relasi baru dapat merubah segalanya (Ritzer \& Stepnisky, 2019). Perubahan ini berkenaan dengan relasi tanggung jawab baru yang memungkinkan datangnya dua hal yaitu marabahaya seperti kekerasan dan penindasan dalam rumah tangga (Azwar, Muliono, \& Permatasari, 2018) dan atau kebaikan-kebaikan yang merefleksikan fungsionalitas eksistensi keluarga (Naldini, 2017). Tingkatan dalam siklus kehidupan ini secara kasat mata sebagai wujud simbol yang memiliki relasi dengan religi dan sistem kebudayaan.

Tindakan simbolis dalam ritual mandi merupakan bagian sangat penting dan tidak mungkin dapat ditinggalkan begitu saja. Manusia harus melakukannya sebagai simbolisme komunikasi dengan yang transenden. Upacara ini merupakan warisan turun temurun dari generasi tua ke generasi muda. Ritual mandi sekalipun memperlihatkan pada kepentingan dua mempelai, pada dasarnya juga memiliki fungsi sosial untuk mengontrol secara 
akomodatif tentang perilaku, suasana hati, perasaan dan nilai kelompok atau komunitas secara keseluruhan.

Menurut Koentjaraningrat (1990) ritual merupakan sistem aktifitas atau rangkaian tindakan yang ditata oleh hukum yang berlaku di masyarakat berhubungan dengan berbagai peristiwa yang biasanya terjadi dalam masyarakat bersangkutan (Koentjaraningrat, 1990). Woodward (1989) ritual adalah "a set or series of acts, usually involving religion or magic, with the sequence estabilished by tradition." Ritual selalu melibatkan agama atau magi yang dikulturasikan melalui tradisi. Pelibatan ini dapat dimaknai sebagai suatu yang kompleks, yang oleh Geertz (dalam Fitria, 2012) sebagai sistem simbol. Geertz menafsirkan simbol sebagai yang menciptakan perasaan dan motivasi pada manusia dengan memformulasikan konsepsi mengenai aturan umum dari eksistensi dan memakai konsepsi tersebut dengan situasi faktual manusia. Sehingga, perasaan dan motivasi secara unik tampak realistik.

Simbol dapat merepresentasikan dari dua hal tertentu yang saling terkait atau mengekspresikan hal-hal yang tidak dapat dijelaskan melalui bahasa verbal. Geertz (dalam Fitria, 2012) melihat simbol sebagai dasar yang digunakan dalam apa yang disebut konsepsi. Konsepsi itu yang menjadi arti dari simbol. Konsepsi itu merupakan ide, sikap, penilaian, formulasi dan abstraksi dari pikiran dan pengalaman dituangkan dalam representasi konkrit. Secara lebih rigid, sistem simbol memiliki sifat yang dimaknai sebagai sumber informasi eksternal dan dapat memberikan konsepsi yang bisa didefinisikan secara internal. Manusia membutuhkan konsepsi internal melalui simbol eksternal. Simbol eksternal ini direpresentasikan dalam bentuk pagar mayar dan berbagai ornemennya.

Menggunakan pendekatan Geertz (dalam Fitria, 2012)mengenai sistem simbol, sistem ritual dapat dimaknai sebagai sebuah model. Model memiliki dua arti yaitu "dari" dan "untuk". Arti "dari", berarti proses memanipulasi struktur simbol sesuai dengan konsepsi internal mengenai simbol. Sementara "untuk", konsepsi internal dimanipulasi dalam hubungannya dengan simbol. Ritual mandi membentuk perasaan dan motivasi yang kuat dan bertahan dalam kehidupan manusia. Simbol-simbol ritual mandi mampu mengekspresikan iklim tentang kehidupan dunia dan apa yang membentuknya. Simbol itu membentuknya dengan menginternalisasi disposisi kepada kelompok masyarakat yang melaksanakan ritual yang memberikan karakter terhadap aktivitas dan kualitas dari pengalaman mereka sebagai masyarakat yang telah hidup dalam jangka waktu yang panjang. Disposisi ini sendiri pada hakikatnya merupakan pola dari aktivitas atau peristiwa, bukan satu kejadian atau satu aktivitas. Secara konsepsional disposisi-disposisi ritual mandi berada dalam dua sentimen yaitu perasaan dan motivasi.

Konsepsi mengenai tatanan eksistensi yang diformulasikan diberikan oleh sistem simbol religi yang terejawantah dalam bentuk ritual mandi. Menggunakan pendekatan Geertz tentang "kekacauan", kekacauan yang berwujud pada rasa kalut dan takut akan terjadi apabila individu tidak mampu memformulasikan konsepsi mengenai struktur atau tatanan eksistensi. Sehingga, simbol selalu memberikan orientasi atau petunjuk bagi manusia atas segala fenomena yang terjadi pada diri maupun pada apa yang berada di luar diri mereka. Kekacauan dimungkinkan bisa terjadi karena keterbatasan kapasitas analitis manusia, keterbatasan kapasitas menahan penderitaan, dan karena keterbatasan kapasitas penilaian moral manusia.

Di antara harapan dan rasa takut, tradisi mandi pengantin sebagai sebuah jalan dalam mana manusia memahami makna fenomena yang dan yang mungkin terjadi untuk mengatasi tatanan eksistensi. Pemaknaan ini terus dikonstruksi sebagai sebuah pencarian menemukan jawaban misteri hidup meskipun dimungkinkan adanya keterbatas kapasitas analitis mereka sebagai masyarakat. Tanpa penemuan ini, meskipun jawaban itu sendiri tidak konsisten dan cenderung tidak akurat, maka kekacauan dalam diri manusia secara kolektif dan secara individu terjadi. Religi memberi perannya pada tataran ini sebagai pemberi konsepsi mengenai fenomena yang tidak dapat dipahami seutuhnya. Sebab itu, terdapat empat jenis air dan doa yang menyertainya. Juga terdapat kalimat-kalimat doa kepada yang trasenden apakah dalam bentuk shalawat maupun dalam bentuk yang lain yang diiringi dengan musik.

Rasa takut manusia merupakan refleksi psikologis yang tidak dapat dihindarkan. Di situlah manusia selalu membutuhkan kehendak untuk bergantung (baca Nietszhe Indrajaya, 2010). Manusia memiliki keterbatasan kapasitas dalam menahan penderitaan. Masalah kehidupan yang dihadapi dapat membuat manusia menderita. Manusia tidak akan pernah mampu menghindari semua penderitaan yang dialaminya. Dengan 
ketidakmampuan untuk menghindar dan terbatasnya kapasitas menahan penderitaan itu, kekacauan dalam diri manusia bisa terjadi. Ritual ini menjadi dan memberikan semacam tuntunan, rasa aman, dan tempat berlindung dari penderitaan yang mungkin akan dialami seperti peceraian di masa depan, umur anak yang tidak panjang, retaknya rumah tangga, dan berbagai aspek megis yang memberi dampak negatif kepada keluarga. Bagaimanapun, persoalan-persoalan ini adalah sebuah aib bagi masyarakat timur, secara spesial kepada masyarat Banjar.

Untuk itu, individu dan kolektifitas masyarakat terus bergerak ke arah pemenuhan dan aktualisasi diri. Ritual ini juga merefleksikan kenyataan sosial dimana manusia dihadapkan pada rasa tidak aman akan segala sesuatu, termasuk menyangkut dirinya seperti kematian, kemiskinan, rasa sakit, perceraian. Hal ini secara langsung memaksa untuk menilai apa yang baik dan apa yang buruk bagi diri dan keluarga. Namun dengan kemampuan yang terbatas manusia perlu mencari sesuatu yang lain sebagai pengarah. Ritual mandi dimungkinkan terdapat etos dan pandangan tentang dunia, yang oleh Geertz, dapat menjelaskan dinamika yang terjadi dalam motivasi dan perasaan manusia. Rtual mandi memperlihatkan pandangan dunia dari representasi atas figur dan berbagai simbol benda dalam ritual itu. Lebih jauh, nilai dalam ritual diejawantahkan ke dalam kehidupan sehari-hari. Motivasi dan perasaan dalam ritual mandi konsisten dengan pandangan mengenai dunia. Makna ritual mandi merepresentasikan keabadian pertentangan kebaikan dan keburukan. Pentingnya ritual mandi untuk memberikan konsepsi mengenai dunia, diri, dan relasi antar keduanya sehingga harmoni kolektifitas dapat dicapai.

\section{Kesimpulan}

Mandi pengantin dalam masyarakat Banjar menunjukkan bahwa kecemasan dan ketakutan terhadap sesuatu yang mengganggu kehidupan rumah tangga dapat diatasi dengan cara menghormati nilai-nilai sakralitas yang terdapat dalam masyarakat yang telah diwariskan oleh nenek moyang. Masyarakat Banjar berpegang teguh pada nilai-nilai lokal yang diyakini kebenarannya, untuk menjadi pegangan hidup yang akan diwariskan secara turun-temurun. Mandi pengantin menjadi salah satu media bagi masyarakat Banjar untuk menghindari gangguan makhluk ghaib yang akan mengganggu resepsi perkawinan dan kehidupan rumah tangga pengantin kelak. Mandi pengantin dilakukan dengan tujuan untuk membentengi diri dari berbagai gangguan makhluk ghaib.

Ritual mandi pengantin memiliki tiga fungsi, pertama; menghubungkan manusia dengan sang pencipta. Mandi pengantin dapat dijadikan sebagai sarana untuk mendekatkan diri kepada sang pencipta apabila dalam proses pelaksanaannya tidak bertentangan dengan hukum Islam, dan masyarakat tidak menjadikan mandi pengantin sebagai sarana untuk menghindari gangguan makhluk ghaib. Mandi pengantin hanya sebagai lambang atau simbol dari do'a yang diharapkan untuk si pengantin. Adapun do'a yang dibacakan sebagai penutup dalam rangkaian tradisi mandi pengantin adalah doa memohon keselamatan dunia dan akhirat. kedua; sebagai media untuk mematuhi normanorma sosial di tengah masyarakat. Ritual dapat bertindak untuk menciptakan hubungan sosial dan menegakkan norma sosial diantara anggota masyarakat. Tradisi mandi pengantin hanya ada dalam perkawinan adat Banjar dan tradisi ini telah dilakukan oleh nenek moyang terdahulu, sehingga generasi selanjutnya hanya mengikuti apa yang telah diwariskan. Dalam pelaksanaannya masyarakat akan saling bekerjasama dan tolongmenolong untuk mempersiapkan segala sesuatu yang diperlukan agar mandi pengantin dapat terlaksana dengan baik. Ketiga; menolak suatu ketakutan dan kecemasan, dengan dilaksanakannya mandi pengantin, masyarakat Banjar percaya bahwa acara resepsi pengantin akan berjalan dengan baik dan mandi pengantin juga dijadikan sebagai instrumen ketahanan rumah tangga.

\section{Ucapan Terima Kasih}

Penulis sangat berterima kasih kepada semua informan, narasumber, kolega serta pihakpihak terlibat baik dalam proses penelitian maupun penyelesaian artikel ini sehingga artikel ini dapat dipublikasi.

\section{Konflik Kepentingan}

Penulis menyatakan bahwa dalam penulisan dan penyelesaian artikel ini tidak memiliki pada konflik kepentingan tertentu yang dapat memengaruhi kualitas keautentikan artikel ini. 


\section{Daftar Pustaka}

Any, S. (2016). Tradisi Repenan dalam Walimah Nikah Ditinjau dalam Konsep 'Urf (Studi Kasus di Dusun Petis Sari Desa Babaksari Kecamatan Dukun Kabupaten Gresik). UIN Maulana Malik.

Ariska, N. (2017). Tradisi Mencukur Alis pada Saat Walimatul al-'Urs pada Masyarakat Nagari Sintuk Kabupaten Padang Pariaman Ditinjau dari Hukum Islam. UIN Imam Bonjol Padang.

Azwar, W., Muliono, \& Permatasari, Y. (2018). Feminisasi Kemiskinan; Studi Tentang Pengemis Perempuan Pada Masyarakat Matrilinial Minangkabau Di Sumatera Barat, Indonesia. Musawa; Jurnal Studi Gender Islam, 17(2), 165-182.

Britannica. (2021). Marriage Encyclopedia Britannica. Retrieved from Britannica website: https://www.britannica.com/topic/marriage

Dharma, F. A. (2019). Konstruksi Realitas Sosial: Pemikiran Peter L. Berger Tentang Kenyataan Sosial. Kanal: Jurnal Imu Komunikasi, 8(1), 1-9. https://doi.org/10.21070/kanal.v

Fitria, V. (2012). Interpretasi Budaya Clifford Geertz: Agama sebagai Sistem Budaya. Sosiologi Reflektif, 7(1), 57-64. Retrieved from www.journal.uta45jakarta.ac.id

Hasbullah, N., \& Syahran Jailani, M. (2020). Tradisi Ritual Bepapai Suku Banjar: Mandi Tolak Bala Calon Pengantin Suku Banjar Kuala-Tungkal Provinsi Jambi, Indonesia. Khazanah: Jurnal Studi Islam Dan Humaniora, 18(2), 287-308. Retrieved from http://dx.doi.org/10.18592/khazanah.v18i2.3920

Hendro, E. P. (2020). Simbol: Arti, Fungsi, dan Implikasi Metodologisnya. Jurnal Imiah Kajian Antropologi, 3(2), 160.

Humaeni, A. (2015). Ritual, Ketidakpercayaan Lokal dan Identitas Budaya Masyarakat Ciomas Banten. El Harakah, 17(2), 157-181.

I Gede, W. (2019). Antropologi Budaya. PT Citra Aditya Bakti.

Indrajaya, F. (2010). Refleksi Pandangan Nietzsche Terhadap Moralitas dan Kepentingan Diri. Humaniora, 1(2), 213-220.

Koentjaraningrat. (1990). Sejarah Teori Antropologi. Jakarat: UI Press.

Maskurin. (2017). Persepsi Masyarakat tentang Tradisi Piduduk dalam Pernikahan Adat Banjar Persfektif 'Urf (Studi di Kelurahan Sidomulyo, Kecamatan Samarinda Mir, Kalimantan Timur). UIN Maulana Malik Ibrahim Malang.

Mustofa, B. (1967). Praktek Buwuhan Pada Walimah Al-'Ursy Perspektif Maslahah (Studi Desa Berlian Makmur Kecamatan Sungai Lilin Kabupaten Musi Banyuasin Sumatera Selatan). UIN Sunan Kalijaga.

Naldini, M. (2017). The Sociology of Families. In K. O. Korgen (Ed.), The Cambridge Handbook of Sociology (pp. 297-304). Cambridge: Cambridge University Press. https://doi.org/10.1017/9781316418376.029

Neliyanti, S. (2020). Tradisi Walimatul 'Urs Perspektif Hukum Islam (Studi Kasus Desa Tulung Aman Kecamatan Marga Tiga Kabupaten Lampung Timur). IAIN Metro.

Nindito, S. (2013). Fenomenologi Alfred Schutz: Studi tentang Konstruksi Makna dan Realitas dalam Ilmu Sosial. Jurnal ILMU KOMUNIKASI, 2(1), 79-95. https://doi.org/ 10.24002/jik.v2i1.254

Procario-Foley, E. G. (2004). Marriage Rituals. In Encyclopedia of religious rites, rituals and festivals (pp. 230-236). Rautledge. Retrieved from http://www.britannica.com/EBchecked/topic/366152/marriage

Purnadi. (2008). Analisis Hukum Islam Terhadap Pelaksanaan Resepsi Pernikahan (Walimatul 'Urs) Di Desa Kebloran Kec. Kragan Kab. Rembang. Institut Agama Islam Negeri Walisongo.

Putra, A. (2014). Tradisi Cukua Abuak Buruak pada Walimatul 'Urs di Kecamatan Pauh Ditinjau dari Hukum Islam. UIN Imam Bonjol Padang.

Ritzer, G., \& Stepnisky, J. (2019). Teori Sosiologi Klasik (Terjemahan). Yogyakarta: Pustaka Pelajar.

Shalihin, M. (2016). Aturan Adat yang Mengharuskan Memakai Tingkuluk Bagi Masyarakat Perempuan yang Datang pada Walimatul al-'Urs di Nagari Koto Gadang. UIN Imam Bonjol Padang.

Southey, E. (2020). Fascinating Wedding Traditions From Around the World. Retrieved from Wedelf website: https://wedelf.com/wedding-traditions-around-the-world/

Sulaiman, A. (2016). Memahami Teori Konstruksi Sosial Peter L. Berger. Society, 4(1), 1522. https://doi.org/10.33019/society.v4i1.32 
Sumarlin, L. (2015). Tradisi Perkawinan Kerubuhan Gunung dalam Pandangan Tokoh Masyarakat. Jurisdictie: Jurnal Hukum Dan Syariah, 6(1), 16. https://doi.org/10.18860/j.v6i1.4086

Turner, B. S. (2010). Sosiologi Agama. Yogyakarta: Pustaka Pelajar.

Turner, B. S. (2012). Teori Sosial dari Klasik sampai Postmodern (Terjemahan). Yogyakarta: Pustaka Pelajar.

Woodward, M. (1989). Islam in Java: normative piety and mysticism in the Sultanate of Yogyakarta. University of Arizona Press, Tucson; Association for Asian Studies Monograph, 45.

Yosofi, S. (2017). Adat Kasua Papan dalam Walimatul al-'Urs di Nagari Tanjung Barulak Kecamatan Batipuh Kabupaten Tanah Datar. UIN Imam Bonjol Padang. 